\title{
Spatial and temporal variation of benthic macroinvertebrates in the Nam Gnom Basin receiving discharged waters from the Nam Theun 2 Reservoir (Lao PDR)
}

\author{
Variabilité spatio-temporelle des macro-invertébrés benthiques \\ du bassin de la Nam Gnom recevant les eaux du Réservoir \\ Nam Theun 2 (RDP du Laos)
}

\author{
S. Clavier ${ }^{(1)}$, M. Cottet $^{(2)^{\star}}$, P. Favriou ${ }^{(2)}$, S.S. Phabmixay ${ }^{(2)}$, P. Guédant ${ }^{(2)}$ \\ (1) Hydreco, Lab. Environnement de Petit-Saut, BP 823, 97388 Kourou Cedex, French Guyana \\ (2) Nam Theun 2 Power Company Limited (NTPC), Environment \& Social Division - Water Quality \\ and Biodiversity Dept.-Gnommalath Office, PO Box 5862, Vientiane, Lao PDR \\ mcottet.lao@gmail.com
}

\begin{abstract}
In order to assess the impact of water release in the downstream area of the Nam Theun 2 Reservoir (Lao PDR), the spatial and temporal variation of benthic macroinvertebrates was explored. Between 2010 and 2012, five sites were monitored in the Nam Gnom Basin, a tributary of the Xe Bangfai River, receiving the turbinated waters. Repeatedtime collections revealed the presence of 109 taxa mainly identified to the family level, attesting to a rich biota. Preliminary results did not show shifts in diversity, population composition, and feeding metrics. Redundancy Analysis indicated that the altitudinal gradient (i.e. altitude and altitude-related variables) remained the major environmental factor influencing the macroinvertebrates distribution before water discharge. The presence of a tributary downstream of the release point, and the respect of the natural river inflow can explain the preservation of natural conditions. More samples and a strengthened ecological knowledge of Southeast Asian macroinvertebrates are still required to confirm these preliminary results.
\end{abstract}

Key words - freshwater invertebrates, Southeast Asia, biomonitoring, hydropower, downstream section

Résumé - Afin d'évaluer l'impact du relâcher des eaux dans la zone aval du Réservoir Nam Theun 2 (RDP du Laos), la variabilité spatio-temporelle des invertébrés aquatiques a été étudiée. Entre 2010 et 2012, cinq sites ont été échantillonnés sur le bassin de la Nam Gnom, un affluent de la rivière Xe Bangfai, qui reçoit les eaux turbinées. Les prélèvements issus du suivi ont permis de mettre en évidence la présence de 109 taxa principalement 
identifiés au niveau de la famille, révélant une richesse importante. Les résultats préliminaires n'ont pas montré de changement majeur des métriques de diversité, de composition des populations et des régimes trophiques. L'analyse canonique de redondance indique que le gradient altitudinal (altitude et variables associées) demeure le facteur environnemental prépondérant affectant la distribution des macro-invertébrés devant les eaux turbinées. La présence d'un affluent en aval du point de relâcher ainsi que le respect du débit naturel de la rivière peuvent expliquer la préservation des conditions naturelles. Des échantillons supplémentaires ainsi qu'une meilleure connaissance de l'écologie des macro-invertébrés de cette région restent nécessaires pour confirmer ces résultats préliminaires.

Mots-clés -invertébrés aquatiques, Asie du Sud-Est, biomonitoring, projet hydroélectrique, zone aval

\section{INTRODUCTION}

In regulated systems, upstream and downstream initial characteristics of rivers are modified e.g. thermal and hydrologic regime, sediment transport, channel morphology, and water quality (Ward \& Stanford, 1979; Dynesius \& Nilsson, 1994; Petts, 1984; Nilsson et al., 2005). These alterations cause changes in assemblage structure of aquatic organisms and bioassessment methods can be used to assess environmental consequences of dams. Macroinvertebrates are widely used for that purpose (Armitage, 1984; Boon, 1988; Moog, 1993; Cortes et al., 1998; Ogbeibu \& Oribhabor, 2002). Their ubiquitous occurrence, high species richness, and limited migration patterns provide a large spectrum of responses to environmental changes including short to long-term cumulative effects (Resh et al., 1995).

In Southeast Asia, the Mekong River basin is recognized for its high hydropower potential (Lauri et al., 2012; Ziv et al., 2012). An estimation of 200 hydropower projects are located in the "Greater Mekong Sub-region", which includes Thailand, Cambodia,
Myanmar, Vietnam, Yunan Province (China) and Lao PDR (Souksavath \& Nakayama, 2013). In 2009, the Mekong River Commission (MRC) estimated that the majority of the projects in the Lower Mekong Basin were located in Lao PDR (MRC, 2010). Interest in using macroinvertebrates to assess environmental changes is growing in the region such as in Vietnam (Hoang \& Bae, 2006; Jung et al., 2008; Hoang et al., 2010) and in Thailand (Mustow, 2002; Getwongsa \& Sangpradub, 2008; Thani \& Phalaraksh, 2008; Boonsoong et al., 2008). However, in Lao PDR, knowledge and use of benthic macroinvertebrates for bioassessment studies remain scarce (Davidson et al., 2006; Pathoumthong \& Vongsombath, 2007).

In the present article, spatial and temporal variability of macroinvertebrates in the downstream section of the Nam Theun 2 (NT2) hydroelectric project (Lao PDR) was investigated. Between 2010 and 2012, five sites were monitored in the Nam Gnom Basin receiving discharged waters from the NT2 Reservoir (Nam Theun Basin). It has been hypothesized that water discharge would lead to taxonomical and functional changes (Jalon et al., 1994; 
Vinson, 2001). More specifically, we hypothesised (i) a reduction of the relative abundance of molluscs as discharged waters had lower conductivity (Chanudet et al., same issue) and diversity and richness of molluscs are known to be closely associated with water conductivity (Dillon, 2000; Horsák, 2006) and (ii) an increase of the relative abundance of collectors-filterers which usually dominate assemblages in downstream area of dams (Schlosser, 1992; Malmqvist \& Eriksson, 1995).

To test these hypotheses, the total macroinvertebrate diversity of the studied area was estimated and the macroinvertebrate assemblages were compared between reference's sites (sites outside of influence of discharged waters) and impacted sites (sites under influence of discharged waters) through a taxonomical and a functional approach. Finally, spatial and temporal distribution of macroinvertebrates was explored through an ordination method.

\section{MATERIAL AND METHODS}

\subsection{Study area}

The NT2 hydropower area is located in the Khammouane Province in central Lao PDR (Fig. 1). The design of the project is characterized by a water diversion from the Nam Theun Basin (sand-stone dominant watershed) to the Xe Bangfai Basin southward (limestone dominant watershed). The Nam Kathang River is a tributary of the Nam Gnom River reaching the Xe Bangfai River few kilometres downstream. The
Nam Kathang River starts after the confluence of two streams: Nam Kathang Noy and Nam Kathang Gnai, flowing into the Regulating Pond, constructed to buffer turbinated waters coming from the Power House. The inflow from the streams in the Regulating Pond is negligible comparing to the one from the Power House (3\% vs. 97\% on an annual basis). Downstream the Regulating Pond, waters are discharged in the Downstream Channel and in the Nam Kathang River through the Regulating Dam. Water release into the river respects an outflow corresponding to the natural inflow with an environmental minimum flow of $0.2 \mathrm{~m}^{3} . \mathrm{s}^{-1}$ while the outflow in the Downstream Channel is in yearly average to $220 \mathrm{~m}^{3} \cdot \mathrm{s}^{-1}$. Water release from the Power House started for test in March 2010 and showed a stable regime since April 2010 when commercial operations began. Detailed features of the project are provided in Descloux et al. (same issue).

Five stations were sampled within the Nam Gnom basin (Fig. 1 and Fig. 2):

(i) Three sites were sampled in the Nam Kathang sub-basin: NKT1, NKT2, and NKT4. NKT1 was located on the Nam Kathang Noy River and NKT2 on the Nam Kathang Gnai River. Both stations were situated upstream of the Regulating Pond in unregulated rivers where no significant human disturbance was observed. NKT4 was located $3.2 \mathrm{~km}$ downstream of the Regulating Pond and upstream of the confluence with the Nam Gnom River. Human activities (cloth washing, fishing, and presence of cattle) were reported at this station.

(ii) Two sites were monitored in the Nam Gnom sub-basin. NGM1 was 


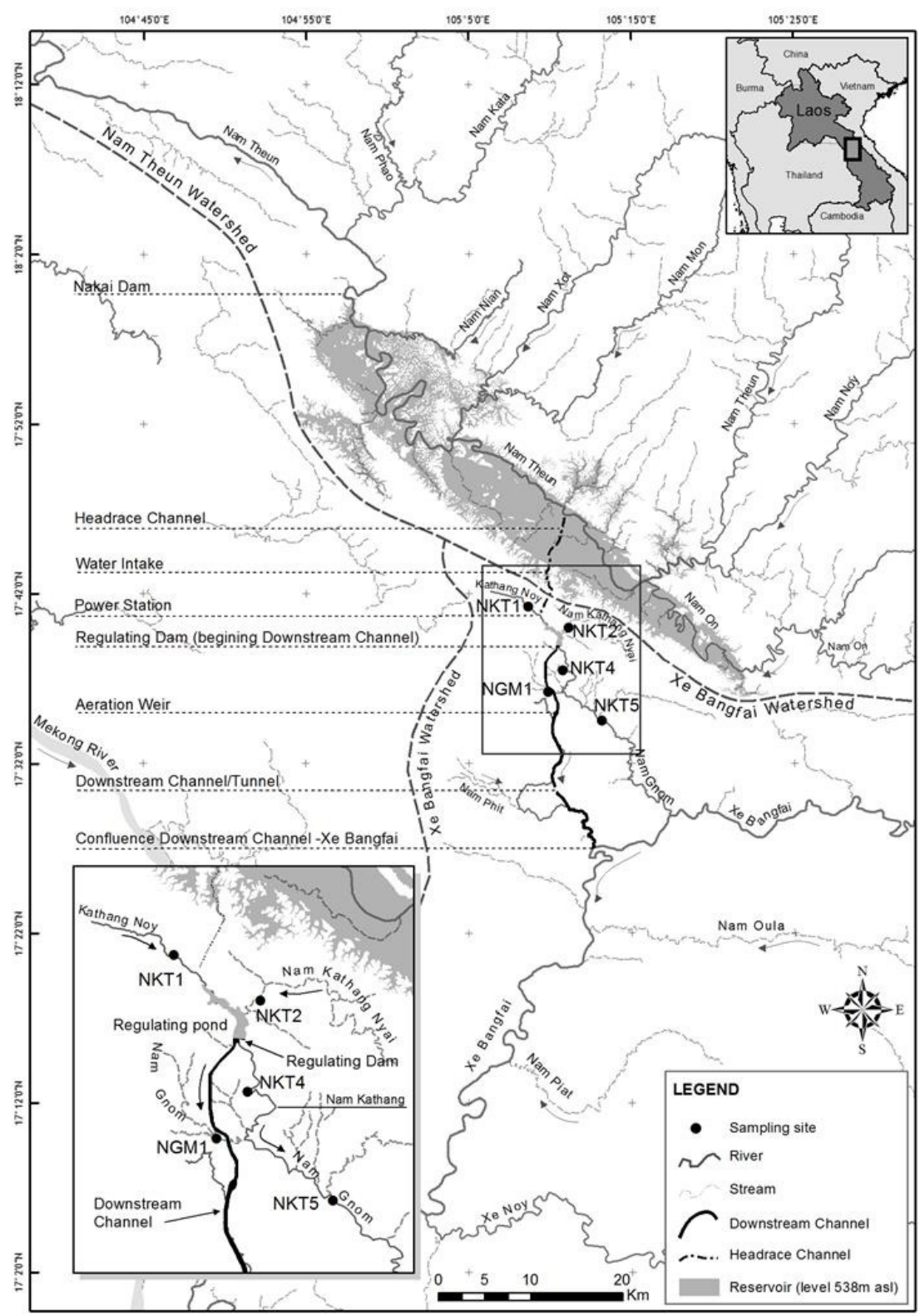

Fig. 1. Location of studies sites in the Nam Gnom Basin.

Fig. 1. Situation géographique des stations prospectées sur le bassin de la Nam Gnom. 


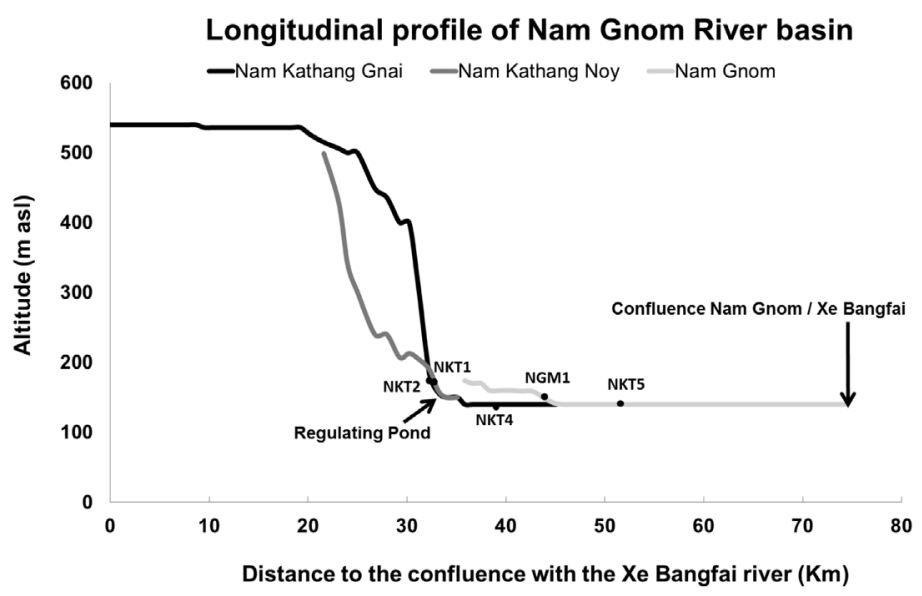

Fig. 2. Location of the station on the longitudinal profile of the Nam Gnom Basin.

Fig. 2. Situation des stations le long du profil longitudinal du bassin de la Nam Gnom.

located $700 \mathrm{~m}$ upstream of the confluence with the Nam Kathang River. NKT5 was situated $6 \mathrm{~km}$ downstream of the confluence with the Nam Gnom River and $17 \mathrm{~km}$ downstream of the Regulating Dam. Both sites were situated downstream of an irrigation dam interrupting the continuum of the Nam Gnom River. Agriculture, presence of cattle, fishing and cloth washing/bathing activities were reported to these stations.

Among the five stations, only NKT4 and NKT5 were influenced by the water release of the NT2 hydropower plant.

\subsection{Aquatic invertebrates sampling and identification}

Field collections were made during 6 campaigns numbered $\mathrm{C} 1$ to $\mathrm{C} 6$ from January 2010 to April 2012 (Tab. I).

Samplings were carried out twice a year during the low flow period which is a key driver of the structure, function and condition of river ecosystems (Rolls et al., 2012). Each site was sampled during the cool dry season in January and at the end of the warm dry season in April.

C1 was sampled 2 months before the beginning of water release from the NT2 Reservoir (April 2010) and NKT4 was sampled only until January 2011 (C3). A preliminary study comparing the station with NKT5 (unpublished results) underlined similitude between both stations. After the campaign C3, NKT4 was abandoned and NKT5 became the downstream reference station. Sampling of NKT1 could not be carried out in April 2010 (C2) because of low water level $(<1 \mathrm{~cm})$.

The protocol used corresponds to a multi-habitat sampling method. At each station, defined as twice the bankfull width, eight samples were collected with a surber sampler (area of $1 / 20 \mathrm{~m}^{2}$, mesh size $500 \mu \mathrm{m}$ ) covering proportionally all 
Table I. Summary of field campaigns.

Tableau I. Synthèse des campagnes d'échantillonnage.

\begin{tabular}{lcccccccc}
\hline \multicolumn{1}{c}{ Date } & Season & $\begin{array}{c}\text { Discharging waters } \\
\text { from NT2 Reservoir }\end{array}$ & Code & NGM1 & NKT1 & NKT2 & NKT4 & NKT5 \\
\hline January 2010 & Cool dry & 2 months before & C1 & X & X & X & X & X \\
April 2010 & Warm dry & 1 month after & C2 & X & - & X & X & X \\
January 2010 & Cool dry & 10 months after & C3 & X & X & X & X & X \\
April 2011 & Warm dry & 13 months after & C4 & X & X & X & - & X \\
January 2012 & Cool dry & 22 months after & C5 & X & X & X & - & X \\
April 2012 & Warm dry & 25 months after & C6 & X & X & X & - & X \\
\hline
\end{tabular}

habitat types with a share of at least $5 \%$ coverage. Samples were preserved with $8 \%$ formalin on the field. At the laboratory, aquatic invertebrates' samples were sorted and identified to the family level according to Dudgeon (1999) and Sangpradub \& Boonsoong (2006). All biological materials were further preserved in alcohol $75 \%$ and were housed in a collection at the Aquatic Environment Laboratory of Nam Theun 2 Power Company.

\subsection{Environmental variables}

Water temperature, dissolved oxygen (DO), pH, conductivity, and turbidity were directly measured in situ using a calibrated HACH HQ40d-multi probe and a HACH 2100P Turbidimeter.

Two physical variables were recorded in the field to characterise habitat:

(i) Relative abundance of substrates. They were categorized as follows: $\%$ of aquatic vegetation (macrophytes, bryophytes, and emerged spermatophytes), \% of submerged coarse organic elements (roots, trunks), $\%$ of mud $(<0.5 \mathrm{~mm}), \%$ of sand (particle size $0.5-2.5 \mathrm{~mm}$ ),
\% of gravels $(2.5-25 \mathrm{~mm}), \%$ of pebbles $(25-250 \mathrm{~mm})$, and $\%$ of boulders (>250 mm).

(ii) Current velocity $\left(\mathrm{V}, \mathrm{cm} \cdot \mathrm{s}^{-1}\right)$. Five classes were identified: $V>150$, $150>V>75,75>V>25,25>V>5$ and $\mathrm{V}<5$.

A mapping of habitats at each station is provided Appendix 2 .

Mean values, minimum, and maximum of the physico-chemical and habitat variables are shown in Table II.

\subsection{Data analysis}

To explore taxonomical and functional changes in the macroinvertebrates assemblage, mean values, minimum, and maximum of diversity, composition, and functional metrics were calculated (Tab. III).

Diversity metrics included the taxonomic richness ( $S=$ number of taxa), density (ind. $\mathrm{m}^{-2}$ ), Shannon-Wiener diversity index $\left(H^{\prime}=-\Sigma p_{i} \mid n p_{i}\right)$, and Pielou evenness index $\left(E=H^{\prime} / \mathrm{InS}\right)$, where $p_{i}=n_{i} / N, n_{i}=$ abundance of the taxon $\mathrm{i}, \mathrm{N}=$ total abundance.

Composition metrics included the \% of Crustacea, \% of Annelida, \% EPT 


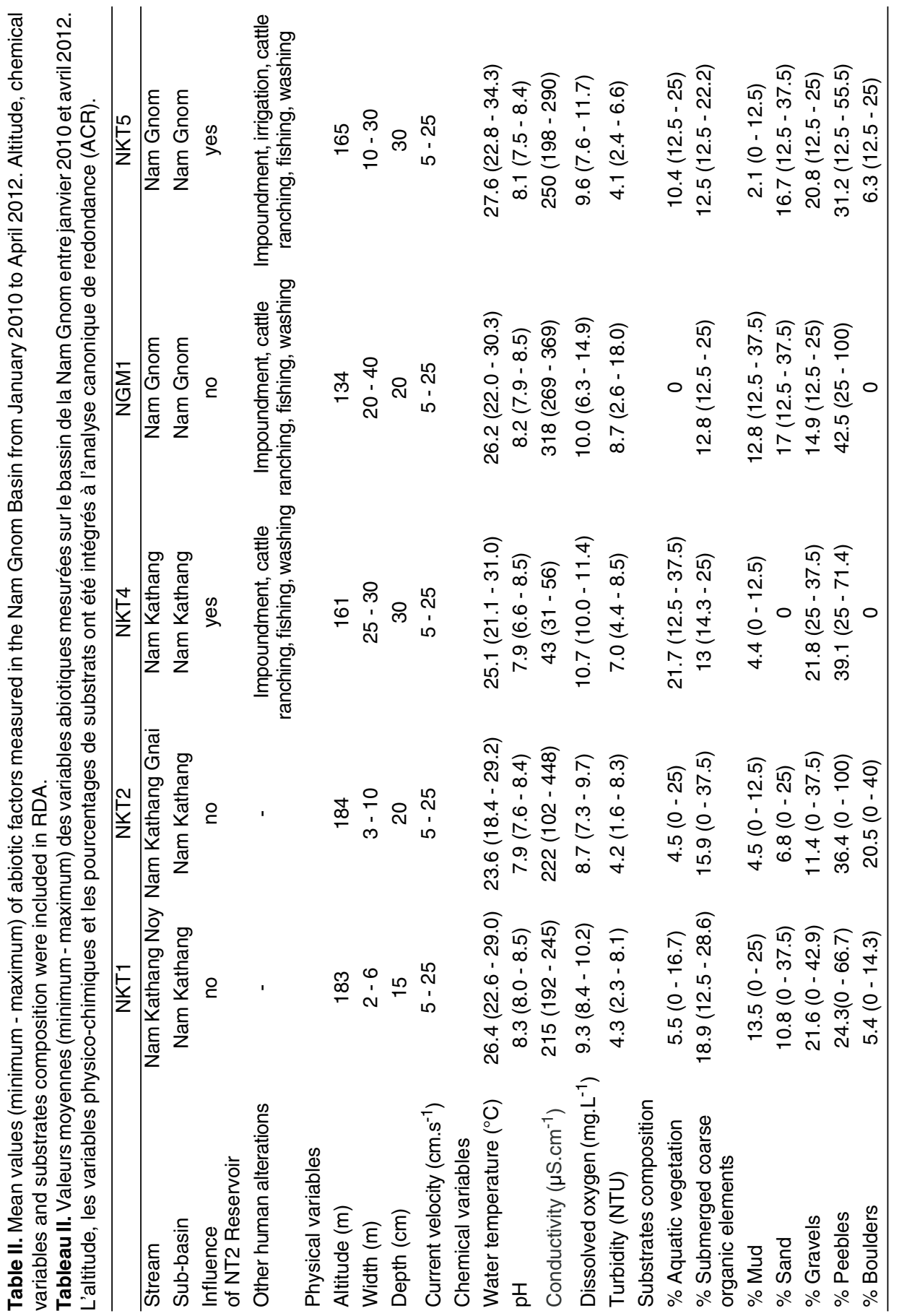




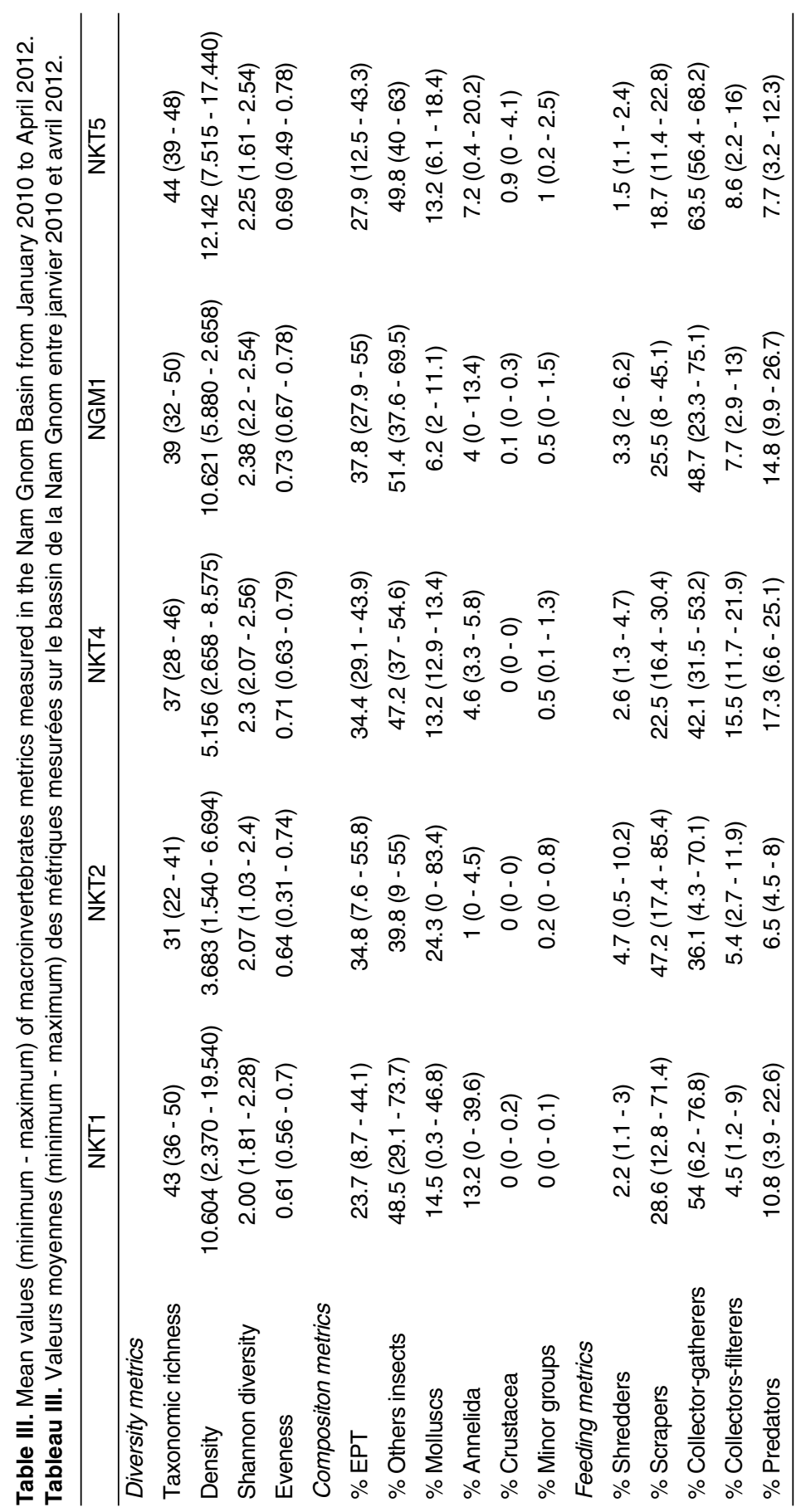


(Ephemeroptera, Plecoptera and Trichoptera), \% of other insects (e.g. Coleoptera, Hemiptera, etc.), \% Molluscs, and \% of minor groups (i.e. Hydracarina, Nematomorpha and freshwater planarians).

Feeding metrics included the \% of five functional feeding groups (FFG). FFG were assigned according to Merrit et al. (2008) and defined according Cummins \& Klug (1979) as follows:

(i) Scrapers (Sc) which consume algae and associated material;

(ii) Shredders (Sh), which consume leaf litter or other Coarse Particulate Organic Matter (CPOM particles $>1 \mathrm{~mm}$ );

(iii) Collector-gatherers (Co-Ga), which collect Fine Particulate Organic Matter $(0.45 \mu \mathrm{m}<$ FPOM particles $<1 \mathrm{~mm}$ ) from the stream bottom;

(iv)Collectors-filterers (Co-Fi), which collect FPOM from the water column using a variety of filters;

(v) Predators (Pr), which feed on other consumers.

In addition, a species-accumulation curve (method exact, function "specaccum") and the estimator of species richness Chao 1 (function "specpool") were used on the whole taxonomic data set to estimate the representativeness of the sampling and estimate the diversity of the benthic macrofauna inhabiting the Nam Gnom basin.

A constrained ordination was conducted to explore spatial and temporal organization of sites and macroinvertebrates assemblage. A previous Detrended Correspondence Analysis (DCA) (function "decorana") displayed short gradient lengths (<4 standard units) indicating that a linear model was the most valuable (ter Braak \& Smilauer, 1998). A Redundancy Analysis (RDA) (function "rda") was hence processed. Rare taxa (density <0.1\%) were previously discarded (Appendix 1). Environmental data set included altitude, chemical variables and substrate composition (Tab. II). We also tested inter-annual (Year) and intra-seasonal (January vs. April) variation. All data were $\log (X+1)$ transformed with the exception of percentages, for which arcsin transformation was used (Legendre \& Legendre, 1998). Statistical significance of the environmental and macroinvertebrates association was verified with anova $(P<0.05 ; 9,999$ Monte Carlo permutations). Forward selection (function "ordistep") was used ( $\mathrm{P}<0.05$; 9,999 Monte Carlo permutations) to determine significant environmental variables.

Data were analysed using $R$ statistical software (R Core Team Development, 2013) and package Vegan (Oksanen et al., 2007). Temporal evolution of S, density, \% Molluscs, and \% Co-Fi were plotted with GraphPad Prism $^{\circledR} 6.0$ (GraphPad Software, San Diego, USA).

\section{RESULTS}

\subsection{Environmental variables}

Sampling sites represented a range of low altitude (134-184 metres above sea level; Tab. II and Fig. 2) streams (channel width: 2-40 m, water depth: 15-30 cm; Tab. II). Pebbles and gravels were the most common substrates in 
the Nam Gnom basin. Sand were mainly found in stations downstream (NGM1 and NKT5) while large boulders were widely represented at NKT2 ( mean $=20.5 \%$ of the total substrates).

The predominance of discharged waters coming from the NT2 Reservoir was confirmed by the analysis of the conductivity (Tab. II). In the Nam Kathang Noy (NKT1) and in the Nam Kathang Gnai (NKT2) average conductivity was $215 \mu \mathrm{S} . \mathrm{cm}^{-1}$ and $222 \mu \mathrm{S} . \mathrm{cm}^{-1}$ respectively, whereas it dropped down to $43 \mu \mathrm{S} . \mathrm{cm}^{-1}$ at NKT4, few kilometres downstream of the Regulating Dam. After the confluence with the Nam Gnom River (NGM1, mean conductivity $\left.=318 \mu \mathrm{S} . \mathrm{cm}^{-1}\right)$ the conductivity increases to an average value of $250 \mu{\mathrm{S} . \mathrm{cm}^{-1}}^{-1} \quad$ (NKT5). Discharged waters did not alter the other parameters which showed close values between upstream and downstream sites. During the six campaigns, all sites showed relatively high DO (mean for all sites and campaigns $=9.5 \mathrm{mg} \cdot \mathrm{L}^{-1}$; S.D. $=1.7$ ), temperature (mean for all sites and campaigns $=25.8^{\circ} \mathrm{C}$; S.D $=3.8$ ), alkaline $\mathrm{pH}$ (mean for all sites and campaigns $=8.1$; S.D. $=0.4$ ) and low turbidity (mean for all sites and campaigns = 5.4 NTU; S.D. = 3.7).

\subsection{Macroinvertebrates survey}

3.2.1 General patterns of macroinvertebrates in the Nam Gnom basin

A total of 109 macroinvertebrates taxa were collected in the Nam Gnom basin from January 2010 to April 2012 (Appendix 1). During the six sampling campaigns 69,72 and 78 taxa were collected at NKT2, NGM1, and NKT5 respectively. At NKT1, 77 taxa were collected during the five sampling campaigns and 55 at NKT4 during the three sampling campaigns. The speciesaccumulation curve processed in the Nam Gnom Basin did not reach asymptote (Fig. 3) indicating that more samples would be required to estimate the total richness. The richness estimator Chao 1 points out the possible presence of 139 taxa (S.D. = 17.3) within the entire Nam Gnom basin. Consequently, sampling covered around $78.4 \%$ of the potential total number of macroinvertebrates' taxa.

Minimum and maximum values of taxonomic richness and density were observed in sites unaffected by the NT2 project suggesting an important natural variability (Tab. III). 22 taxa and 2,370 ind. $\mathrm{m}^{-2}$ were collected at NKT2 (January 2011) whereas 50 taxa and 19,540 ind. $\mathrm{m}^{-2}$ were collected at NKT1 (January 2012) (Figs. 4a and 4b). Lowest diversity $\left(H^{\prime}=1.03\right)$ and evenness $(E=0.32)$ indices were also observed at NKT2 in April 2010 (Tab. III). On the other hand, maximum values of diversity $\left(H^{\prime}=2.56\right)$ and evenness $(E=0.79)$ indices were both observed downstream the regulating dam at NKT4 (Tab. III). At this site, taxonomic richness and density decreased after the beginning of water discharge (Figs. $4 \mathrm{a}$ and $4 \mathrm{~b}$ ) but the same pattern was also observed in sites unaffected by the NT2 project. For example, between January 2010 and January 2011, taxonomic richness varied from 31 to 22 taxa at NKT2 and density from 12,920 ind. $\mathrm{m}^{-2}$ to 5,880 ind. $\mathrm{m}^{-2}$ at NGM1. At NKT5, taxonomic richness remained stable during the study period (Fig. 4a) whereas density increased (Fig. 4b) 


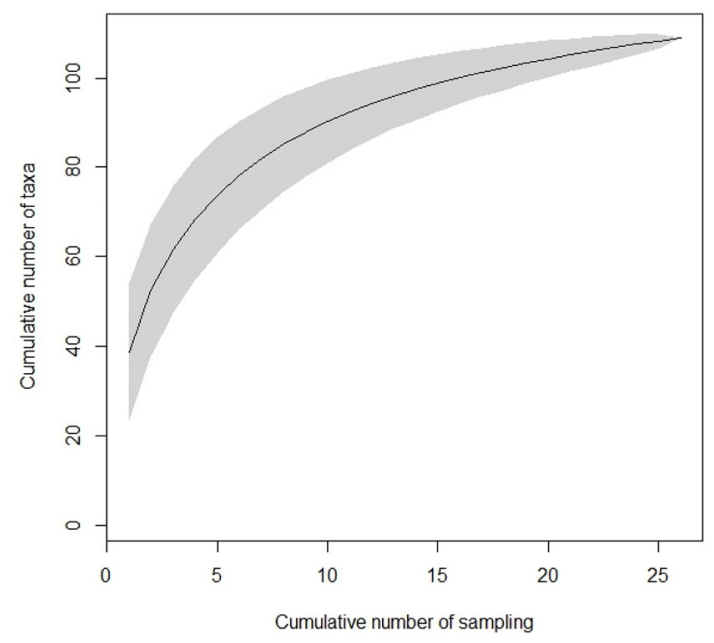

Fig. 3. Species-accumulation curve by cumulative number of sampling ( 8 surber samples/site) for all stations and dates sampling $(n=26)$. Shaded area indicates confidence intervals from standard deviation.

Fig. 3. Courbe d'accumulation de la richesse taxonomique en fonction du nombre d'échantillonnage (8 prélèvements au surber/site) sur l'ensemble des stations d'étude et des dates d'échantillonnages $(n=26)$. La portion grisée représente l'intervalle de confiance de l'écart type.

from 8,093 ind. $\mathrm{m}^{-2}$ (January 2010) to 15,105 ind. $\mathrm{m}^{-2}$ (April 2012).

\subsubsection{Taxonomic composition}

Diptera (37.3\%), Ephemeroptera (23.6\%) and Mollusca (12\%) were dominant in samples whereas Crustacea $(0.2 \%)$ and Plecoptera $(1.3 \%)$ were the less represented. Trichoptera (20 families) and Coleoptera (16 families) were the richest groups followed by Hemiptera (13 families) and Mollusca (13 families; Appendix 1). Insects remained dominant at all sampling sites representing between $66.3 \%$ (NKT2) and $89.7 \%$ (NGM1) of the macroinvertebrates community. The EPT group (Ephemeroptera, Plecoptera, and Trichoptera) constituted an important part of the community (Tab. III) ranging from
$23.7 \%$ (NKT5) to $37.8 \%$ (NGM1) but Plecoptera remained generally scarce $(<1 \%)$. Beside insects, molluscs were the second most important group reaching $24.3 \%$ at NKT2. At all sampling sites, annelids showed low relative abundances except at NKT1 where they reached $13.2 \%$. Minor groups and crustaceans accounted for $1 \%$ or less in the Nam Gnom basin.

Surprisingly, relative abundance of molluscs did not decrease at NKT4 and NKT5 after receiving poor-mineralised waters (Fig. 4c, Tab. II). Populations remained identic at NKT4 during the whole study. In January 2010, relative abundance of molluscs was $13.4 \%$, while it was $12.9 \%$ in April 2010 and $13.2 \%$ in January 2011. At NKT5, population of molluscs increased after receiving discharged waters. Three 
a)

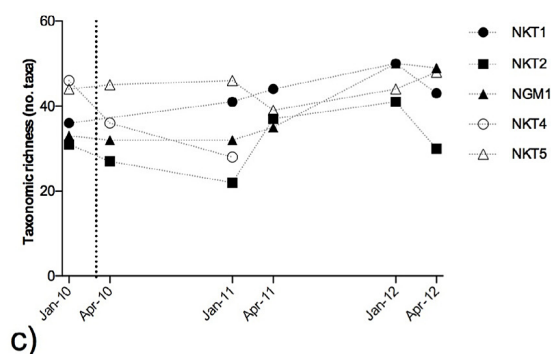

c)

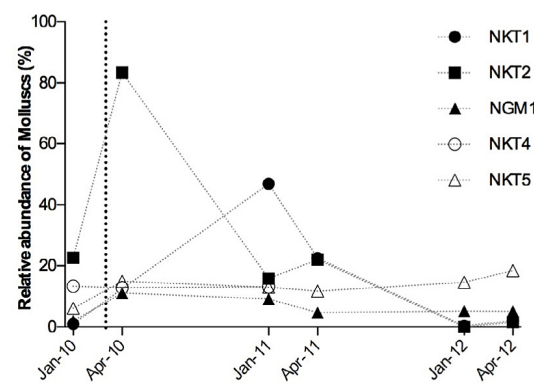

b)

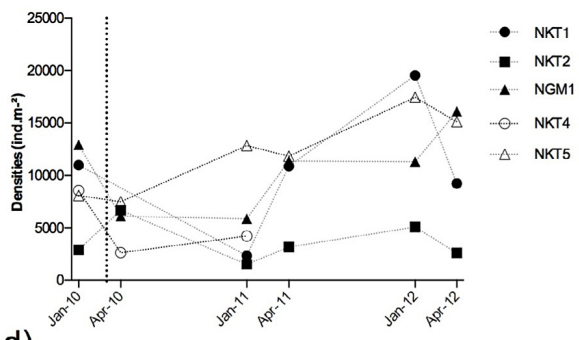

d)

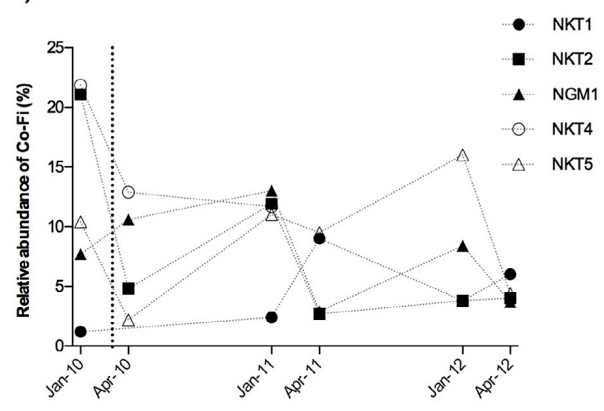

Fig. 4. Temporal variation of taxonomic richness (a), densities (b), relative abundance of mollsuscs (c) and relative abundance of collector-filterers (d) in the Nam Gnom basin. Vertical line corresponds to the beginning of water discharged from the Nam Theun 2 Reservoir. White filled labels correspond to sites under influence of discharged waters.

Fig. 4. Variation temporelle de la richesse taxonomique (a), de la densité (b), de l'abondance relative des mollusques (c) et de l'abondance relative des collecteurs-filtreurs (d) sur le bassin de la Nam Gnom. La ligne verticale indique le début du turbinage des eaux du Réservoir Nam Theun 2. Les labels blancs correspondent aux sites sous influences des eaux turbinées.

months before the beginning of hydropower operation (January 2010), molluscs represented $6.1 \%$ of the community. Just after the water discharge (April 2010), molluscs represented $14.9 \%$ and $18.4 \%$ two years later (April 2012).

\subsubsection{Functional feeding groups}

The collector-gatherer group (Co$\mathrm{Ga}$ ), ranging from $36.1 \%$ (NKT2) to $63.5 \%$ (NKT1), was dominant at all sampling sites except at NKT2 where scrapers (Sc) dominated (47.2\%)
(Tab. III). Sc was the second most important dietary group. Minimum average $\mathrm{Sc}$ value was observed at NKT5 $(18.7 \%)$. Other FFG were lower in the Nam Gnom basin. Average contributions of Predators $(\mathrm{Pr})$ and shredders (Sh) did not exceed $17.3 \%$ and $4.7 \%$ respectively. Collector-filterers (Co-Fi) appeared more abundant in sites influenced by discharged waters, especially at NKT4 where they reached $15.5 \%$.

Although average proportion of CoFi appeared to be higher in sites influenced by discharged waters, these 
populations were halved at NKT4 after the beginning of water release (Fig. 4d). In January 2010, Co-Fi represented $21.9 \%$ of the community whereas they represented $11.7 \%$ one year after. At NKT5, Co-Fi remained stable during the study period despite a high seasonal variability.

\subsubsection{Environmental factors influenc-} ing macroinvertebrates communities

The Redundancy Analysis (Figs. 5a and $5 b$ ) explained $23.63 \%$ of the total variance and resulted in a significant model $(P=0.005)$. Axes 1 and 2 accounted for $37.68 \%$ of the explained variation. Axis 1 explained $25.85 \%$ (eigenvalue 6.109) and axis $211.83 \%$ (eigenvalue 2.797) of the variation fit.

Five environmental variables were retained in the RDA model by the forward selection procedure: Altitude $(P=$ 0.005), Year $(P=0.005)$, \% Aquatic vegetation $(P=0.005)$, Conductivity $(P=0.01)$ and \% Boulder that had a marginal effect $(P=0.0486)$ (Fig. 5a).

The first canonical axis associated positively with Altitude $(r=0.768)$, $\%$ Aquatic vegetation $(r=0.088)$, \% Boulder $(r=0.295)$ and negatively with Conductivity $(r=-0.354)$ and Year $(r=$ -0.232) supports a clear altitudinal gradient (Fig. 5a) whereas the association between axis 2 and the environmental variable Year $(r=0.594)$ suggested a temporal gradient. Furthermore, the axis 1 makes a clear distinction between the two sub-basins of the Nam Gnom and the Nam Kathang Rivers. NGM1 and NKT5 (Nam Gnom sub-basin) were located on the negative part and were opposed to NKT4, NKT1 and NKT2 (Nam Kathang sub-basin).
Taxa projection (Fig. 5b) indicated that the Potamanthidae family (Ephemeroptera) was the main contributor of the negative part of RDA axis 1 $(r=-1.147)$ and the Hydrophilidae family (Coleoptera) $(r=0.423)$ the main contributor of the positive part. The Pomatiopsidae family (Gastropoda) was the main contributor of the negative part of the axis $2(r=-0.769)$ and the Leptophlebiidae family (Ephemeroptera) the main contributor of the positive part $(r=0.506)$. Most macroinvertebrates taxa occurred in the negative part of axis 1 and were associated with lowest altitudinal sites.

\section{DISCUSSION - CONCLUSION}

In addition to the initial bioassessment objectives, this study provided valuable inventory of benthic macroinvertebrates families inhabiting a little studied area of Southeast Asia. A total of 109 macroinvertebrates taxa were identified in the Nam Gnom Basin attesting of a rich biota. Prospecting Northern Vietnam, Jung et al. (2008) reported cumulative richness from 61 to 91 families of a wide range of habitat including rivers in national parks. Furthermore, general patterns of diversity were consistent with regional literature. Trichoptera, Hemiptera, and freshwater molluscs were among the most diverse groups. This observation is in line with rivers of the Mekong Basin, known to host one of the highest diversity of these groups (Bogan, 2008; De Moor \& Ivanov, 2008; Polhemus \& Polhemus, 2008; Strong et al., 2008). On the other hand, the low representation of Plecoptera and Crustacean was predictable. 

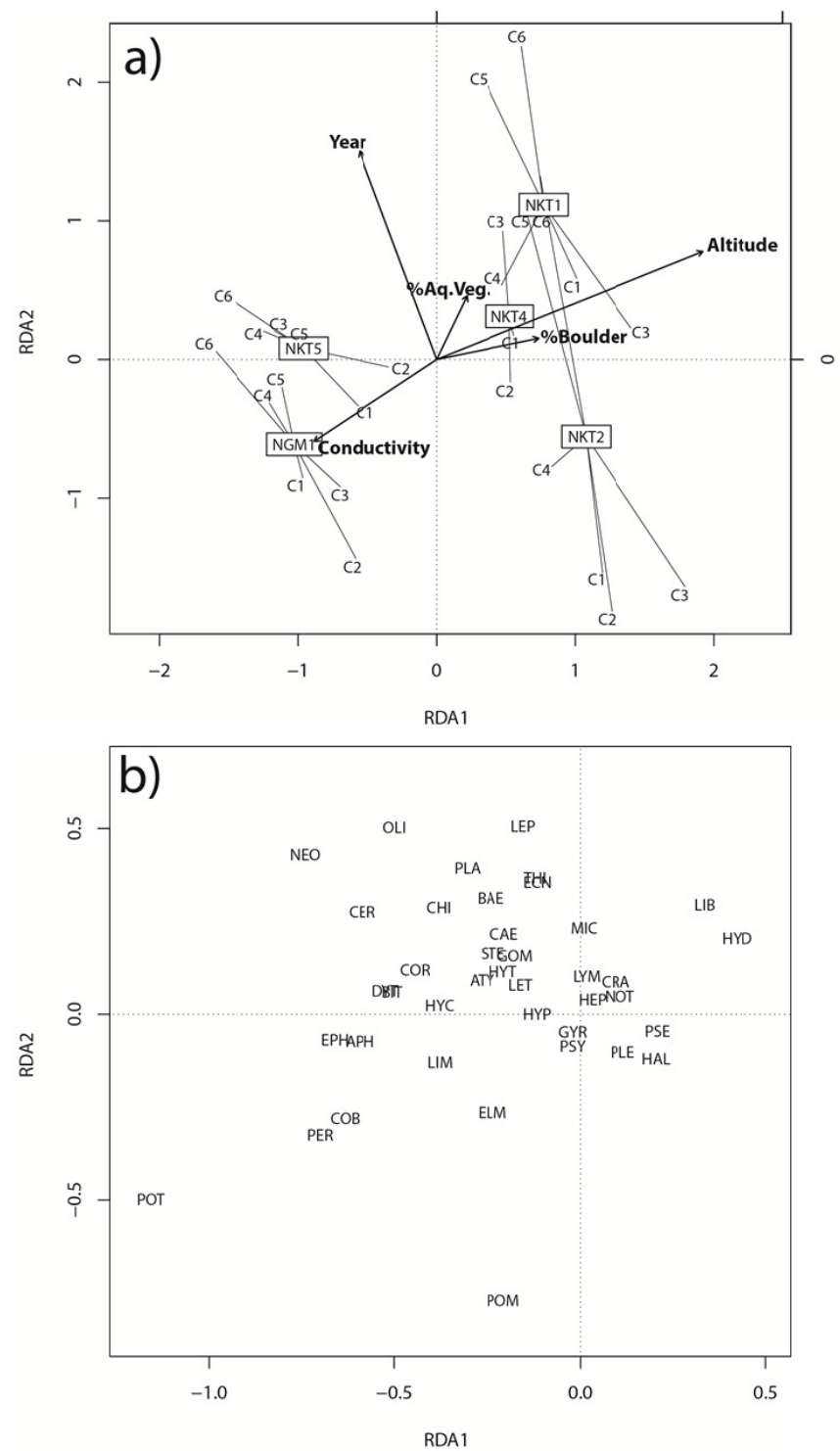

Fig. 5. Axes 1 and 2 of the redundancy analysis (RDA) ordination diagrams. a) Sites-environmenta biplot showing significant environmental variables following forward selection. The mean position of the sites was located at the weighted average of corresponding sites. b) Taxa projection. Full taxa names can be found in Appendix 1.

Fig. 5. Axes 1 et 2 de l'analyse canonique de redondance (ACR). a) Graphique sites-variables environnementales significatives selon la procédure de sélection ascendante pas à pas. La position des sites correspond à la position moyenne pondérée des sites correspondants. b) Projection des taxa. Le nom complet des taxa est disponible en Annexe 1. 
Plecoptera are known to be scarce in tropical streams (Vinson \& Hawkins, 2003) and the surber gear underestimates shrimp abundance due to their high mobility (Ramirez \& Pringle, 1998).

Response of macroinvertebrate assemblages to water discharge indicated no evident reduction of diversity indices neither a shift in composition community. At all sites, the typical dominance of Chironomidae and Baetidae was observed (Pinder, 1986; Suren, 1994; Galdean et al., 2001; Ferrington, 2008). The sensitive families e.g. Ephemeroptera which are known to negatively react to environmental stress (Azrina et al., 2006; Boonsoong et al., 2009), did not show a decline in population among the upstream stations of the Regulating Pond and the downstream stations receiving water discharge. Surprisingly, mollusc's populations didn't decrease in sites located after water discharge. The high representation of macrophytes habitat (Tab. II) at NKT4 and NKT5 could explain the persistence of mollusc populations. Vegetation composition is a key factor explaining the variation in mollusc species (Horsák \& Hájek, 2003).

Furthermore, no functional group changes were apparent. At all sites, the dominance of collector-gatherers was observed, except at NKT2 where scrapers dominated due to the presence of large boulders ( $>2 \mathrm{~m}$ ) with low surface heterogeneity. This habitat was poorly colonised by insects' taxa but was largely covered by freshwater snails feeding on an abundant periphyton (e.g. Pomatiopsiade; Appendix 1). These results suggested that the capacity to process organic matter was not altered by water release. In addition, the shredders group, represented by few taxa (Tab. III), known to decrease under increasing perturbation (Boonsoong et al., 2009), did not show relevant differences between the upstream and downstream stations. However, the use of the functional feeding groups (FFG) determined for temperate taxa and the family level assignment of FFG has clear limitations (Tomanova et al., 2006, Ramírez \& Gutiérrez-Fonseca, 2014). FFG studies at species-level and regionally based, would have allowed more precise conclusion.

In addition, redundancy analysis showed that altitude remained the main driver affecting the distribution of macroinvertebrates taxa in the Nam Gnom Basin before water release. Furthermore, no association among impacted sites was observed. The other environmental factors retained by the forward selection procedure are closely related to altitude. For instance a negative correlation between conductivity and elevation is generally observed (Wilcox et al., 1957; Rundle et al., 1993) and the positive correlation between altitude and the percentage of boulders reflects the sediment transport implying the presence of larger rocks mainly in the upstream part and finer sediments in the downstream part. This altitudinal distribution of habitats is underlined by a clear differentiation of the taxa distribution. For instance, Potamanthidae was the main contributor of the negative part of RDA axis 1 (lower altitude, higher conductivity). The knowledge on the ecology of this family supports this finding as nymphs are known to inhabit downstream sections such as 
fourth-order stream (Munn \& King, 1987). Then, our results are in accordance to literature that underlined that most macroinvertebrates taxa showed a positive correlation with lower altitudinal sites (Jacobsen, 2004). Interannual variation appeared to be a variable playing a significant role on the macroinvertebrates population structure and composition. Pomatiopsidae showed the highest correlation with the temporal gradient suggesting a turnover of populations in accordance to Attwood \& Upatham (2012) who identified natural growth-decline cycles in Thailand and central Lao PDR.

Then, two mains factors may explain the relative conservation of natural conditions:

(i) An environmental minimum flow respecting the natural inflow. Flow regime has a strong influence on the biodiversity of rivers and importance of keeping the flow as close as possible to the natural regime is attested (Stanford et al., 1996; Poff et al., 1997) and confirmed by the interest in restoring natural flow regime to recover biotic integrity all around the world (Sparks, 1995; Petts, 1996; Galat et al., 1998; Sparks et al., 1998; Dudgeon, 2000; Robinson et al., 2003; Attwood \& Cottet, same issue).

(ii) The presence of a tributary downstream of the release point. Tributaries are known to structure longitudinal biotic patterns (Rice et al., 2001) and their importance in regulated rivers are recognized (Petts \& Greenwood, 1985; Stevens et al., 1997). According to the serial discontinuity concept (Ward \&
Stanford, 1983), recovery of large regulated rivers downstream from a dam is limited by relative tributary size. Here, the Nam Gnom River allows to recover biotic integrity of the Nam Kathang River.

Finally, the preliminary results of aquatic invertebrates bioassessment in the Nam Gnom basin allows to draw a general trend of communities in this region. All results of our study are based on a bioassessment at the family-level. Using family level identification is recommended in case of incomplete taxonomic knowledge (Thorne \& Williams, 1997) and is qualified as sufficient to assess environmental disturbance (e.g. in Thailand; Boonsoong et al., 2008). Recent studies conducted in tropical areas showed that family-level resolution successfully detect anthropogenic impairment (Dedieu et al., 2015). However, genus-level would have provided more accurate information on water integrity (Lenat \& Resh, 2001) and on environmental factors influencing communities (e.g. differentiation in the FFG, species-level sensitivity). This approach would have given more confidence to guide management decisions (Rosenberg et al., 1986). Even no significant conclusion could be raised due to the few available data before water release, the study allows to strengthen the local knowledge in terms of macroinvertebrates population and environmental factors that could influence them. Bioassessment is at its early stage in Lao PDR. Additional taxonomical and ecological knowledge of benthic macroinvertebrates in the tributaries of the Mekong River are still required to develop robust 
bioassessment tools, particularly promising in this fast-growing region.

\section{ACKNOWLEDGEMENTS}

This research has been conducted at the Aquatic Environment Laboratory of Nam Theun 2 Power Company in Lao PDR whose Shareholders are Électricité de France, Lao Holding State Enterprise and Electricity Generating Public Company Limited of Thailand.

We would like to thank NTPC, Water Quality and Biodiversity Dept, Aquatic Environment Laboratory (AEL) field sampling and at the laboratory analysis (hydrobiology and chemistry teams). We want also to thank all other NTPC teams for their support during the survey and especially Liankham Payasane (GIS team), the logistic team, and $\mathrm{Mr}$ Paul Dumbrell who reviewed and improved this version of the manuscript as a native English speaker. Additionally, we thank Olivier Dezerald and all the family-owned HYDRECO team, particularly Claire Montigny and Nicolas Dedieu for their appreciated support. Finally, we would like to thank the reviewer for the comments and helpful advices to improve the manuscript.

\section{REFERENCES}

Armitage P.D., 1984. Environmental changes induced by stream regulation and their effect on lotic macroinvertebrate communities. Regul. River: 139-165.

Attwood S.W. \& Cottet M. Malacological and parasitological surveys along the Xe Bangfai and its tributaries in
Khammouane Province, Lao PDR. Hydroécol. Appl. 19 (same issue).

Attwood S.W. \& Upatham E.S., 2012. Observations on Neotricula aperta (Gastropoda: Pomatiopsidae) population densities in Thailand and central Laos: implications for the spread of Mekong Schistosomiasis. Parasite. Vector. 5 (126) : 1-13.

Azrina M.Z., Yap C.K., Rahim Ismail A., Ismail A. \& Tan S.G., 2006. Anthropogenic impacts on the distribution and biodiversity of benthic macroinvertebrates and water quality of the Langat River, Peninsular Malaysia. Ecotox. Environ. Safe. 64 : 337-347.

Bogan A.E., 2008. Global diversity of freshwater mussels (Mollusca, Bivalvia) in freshwater. Hydrobiologia 595 : 139147.

Boon P.J., 1988. The impact of river regulation on invertebrate communities in the UK. Regul. River. 2(3) : 389-409.

Boonsoong B., Sangpradub N. \& Barbour M.T., 2008. Development of rapid bioassessment approaches using benthic macroinvertebrates for Thai streams. Environ. Monit. Assess. 155(1-4) : 129147.

Boonsoong B., Sangpradub N., Barbour M.T. \& Simachaya W., 2009. An implementation plan for using the biological indicators to improve assessment of water quality in Thailand. Environ. Monit. Assess. 165(1) : 205-215.

Chanudet V., Guédant P., Rode W., Guérin F., Serça D., Deshmukh C. \& Descloux S. Evolution of the physico-chemical water quality in the Nam Theun 2 Reservoir for the first 5 years after impoundment. Hydroécol. Appl. 19 (same issue).

Cortes R.M.V., Ferreira M.T., Oliveira S.V. \& Godinho F., 1998. Contrasting impact of small dams on the macroinvertebrates of two Iberian mountain rivers. Hydrobiologia 389(1-3) : 51-61. 
Cummins K.W. \& Klug M.J., 1979. Feeding ecology of stream invertebrates. Annu. Rev. Ecol. Syst.10 : 147-172.

Davidson S.P., Kunpradid T., Peerapornisal Y., Nguyen T.M.L., Pathoumthong B., Vongsambath C. \& Pham A.D., 2006. Biomonitoring of the Lower Mekong and selected tributaries. MRC Technical Paper 13. Mekong River Commission,106 p., Vientiane.

Dedieu N., Clavier S., Vigouroux R., Cerdan P. \& Céréghino R., 2015. A Multimetric Macroinvertebrate Index for the Implementation of the European Water Framework Directive in French Guiana, East Amazonia. River. Res. Appl., doi: 10.1002/rra.2874.

De Moor F.C. \& Ivanov V.D., 2008. Global diversity of caddisflies (Trichoptera: Insecta) in freshwater. Hydrobiologia 595(1) : 393-407.

Descloux S., Guédant P., Phommachanh D. \& Luthi R. Main features of the Nam Theun 2 hydroelectric project (Lao PDR) and the associated environmental monitoring programme. Hydroécol. Appl. 19 (same issue).

Dillon R.T., 2000. The ecology of freshwater molluscs. Cambridge University Press, $509 \mathrm{p}$.

Dudgeon D., 1999. Tropical Asian Streams: Zoobenthos, Ecology and Conservation. Hong Kong University Press, Hong Kong, $830 \mathrm{p}$.

Dudgeon D., 2000. Large-Scale Hydrological Changes in Tropical Asia: Prospects for Riverine Biodiversity The construction of large dams will have an impact on the biodiversity of tropical Asian rivers and their associated wetlands. Bioscience 50(9) : 793-806.

Dynesius M. \& Nilsson C., 1994. Regulation of River Systems in the Northern Third of the World. Science 266 : 753-762.
Ferrington L.C., 2008. Global diversity of nonbiting midges (Chironomidae; InsectaDiptera) in freshwater. Hydrobiologia 595 : 447-455.

Galat D.L., Fredrickson L.H., Humburg D.D., Bataille K.J., Bodie J.R., Dohrenwend J. \& Semlitsch R.D., 1998. Flooding to restore connectivity of regulated, largeriver wetlands natural and controlled flooding as complementary processes along the lower Missouri River. Bioscience 48(9) : 721-733.

Galdean N., Callisto M. \& Barbosa F.A.R., 2001. Biodiversity assessment of benthic macroinvertebrates in altitudinal lotic ecosystems of Serra do Cipó (MG, Brazil). Rev. Bras. Biol. 61(2) : 239-248.

Getwongsa P. \& Sangpradub N., 2008. Preliminary Study on Development of Biotic Index for Rapid Bioassessment in Mekong II Basin (Thailand). KKU Sci. J. 36 (Suppl.) : 122-136.

Hoang D.H. \& Bae Y.J., 2006. Aquatic insect diversity in a tropical Vietnamese stream in comparison with that in a temperate Korean stream. Limnol. 7 : 45-55.

Hoang T.H., Lock K., Dang K.C., De Pauw N. \& Goethals P.L.M., 2010. Spatial and temporal patterns of macroinvertebrate communities in the du River basin in northern Vietnam. J. Freshwater Ecol. 25(4) : 637-647.

Horsák M., 2006. Mollusc community patterns and species response curves along a mineral richness gradient: a case study in fens. J. Biogeography 33(1) : 98-107.

Horsák M. \& Hájek M., 2003. Composition and species richness of molluscan communities in relation to vegetation and water chemistry in the western Carpathian spring fens: the poor-rich gradient. J. Mollus. Stud. 69(4) : 349-357.

Jacobsen D., 2004. Contrasting patterns in local and zonal family richness of stream 
invertebrates along an Andean altitudinal gradient. Freshwater Biol. 49(10) : 1293-1305.

Jalon D., Garcia D., Sanchez P. \& Camargo J.A., 1994. Downstream effects of a new hydropower impoundment on macrophyte, macroinvertebrate and fish communities. Regul. River. 9(4) : 253-261.

Jung S.W., Nguyen Q.H. \& Bae Y.J., 2008. Aquatic insect faunas and communities of a mountain stream in Sapa Highland, northern Vietnam. Limnol. 9(3) : 219-229.

Lauri H., De Moel H., Ward P.J., Räsänen T.A., Keskinen M. \& Kummu M., 2012. Future changes in Mekong River hydrology: impact of climate change and reservoir operation on discharge. Hydrol. Earth Syst. Sci. 9(5) : 6569-6614.

Legendre P. \& Legendre L., 1998. Numerical ecology. 2nd English edition. Elsevier, Amsterdam, $853 \mathrm{p}$.

Lenat D.R. \& Resh V.H., 2001. Taxonomy and stream ecology-the benefits of genus-and species-level identifications. J. N. Am. Benthol. Soc. 20(2) : 287-298.

Malmqvist B. \& Eriksson Å., 1995. Benthic insects in Swedish lake-outlet streams: patterns in species richness and assemblage structure. Freshwater Biol. 34(2) : 285-296.

Merrit R.W., Cummins K.W. \& Berg M.B., 2008. An introduction to the aquatic insect of North America. Fourth Edition. Ed. Dubuque, lowa, $1158 \mathrm{p}$.

Moog O., 1993. Quantification of daily peak hydropower effects on aquatic fauna and management to minimize environmental impacts. Regul. River. 8(1-2) : 5-14.

MRC, 2010. State of the Basin Report 2010. Mekong River Commission, Vientiane, Lao PDR, $123 \mathrm{p}$.

Munn M.D. \& King R.H., 1987. Ecology of Potamanthus myops (Walsh) (Ephemeroptera: Potamanthidae) in a Michigan stream (USA). Hydrobiologia 146 : 71-75.
Mustow S.E., 2002. Biological monitoring of rivers in Thailand: use and adaptation of the BMWP score. Hydrobiologia 479 : 191-229.

Nilsson C., Reidy C.A., Dynesius M. \& Revenga C., 2005. Fragmentation and flow regulation of the world's large river systems. Science 308(5720) : 405-408.

Ogbeibu A.E. \& Oribhabor B.J., 2002. Ecological impact of river impoundment using benthic macro-invertebrates as indicators. Water Res. 36(10) : 24272436.

Oksanen J., Kindt R., Legendre P., O'Hara B., Stevens M.H.H., Oksanen M.J. \& Suggests M.A.S.S., 2007. The vegan package. Community ecology package.

Pathoumthong B. \& Vongsombath C., 2007. Macroinvertebrate Pilot Study for Ecological Health Monitoring in the Lower Mekong Basin. Southeast Asian Water Environment 2, $123 \mathrm{p}$.

Petts G.E., 1984. Impounded rivers: perspectives for ecological management. John Wiley, New York, 326 p.

Petts G.E., 1996. Water allocation to protect river ecosystems. Regul. River. 12(4-5) : 353-365.

Petts G.E. \& Greenwood M., 1985. Channel changes and invertebrate faunas below Nant-Y-Moch dam, River Rheidol, Wales, UK. Hydrobiologia 122(1) : 65-80.

Pinder L.C.V., 1986. Biology of freshwater Chironomidae. Annu. Rev. Entomol. 31(1) : 1-23.

Poff N.L., Allan J.D., Bain M.B., Karr J.R., Prestegaard K.L., Richter B.D., Sparks E.E. \& Schomberg J.C., 1997. The natural flow regime: A paradigm for river conservation and restoration. Bioscience 47 : 769-784.

Polhemus J.T. \& Polhemus D.A., 2008. Global diversity of true bugs (Heteroptera: Insecta) in freshwater. Hydrobiologia 595 : 379-391. 
R Core Team Development, 2013. R: A language and environment for statistical computing. R Foundation for Statistical Computing, Vienna, Austria. URL http:// www.R-project.org/.

Ramírez A. \& Gutiérrez-Fonseca P.E., 2014. Functional feeding groups of aquatic insect families in Latin America: a critical analysis and review of existing literature. Rev. Biol. Trop. 62 : 155-167.

Ramirez A. \& Pringle C.M., 1998. Invertebrate drift and benthic community dynamics in a lowland neotropical stream, Costa Rica. Hydrobiologia 386 : 19-26.

Resh V.H., Norris. R.H., \& Barbour M.T., 1995. Design and implementation of rapid assessment approaches for water resource monitoring using benthic macroinvertebrates. Aust. J. Ecol. 20(1) : 108-121.

Rice S.P., Greenwood M.T. \& Joyce C.B., 2001. Tributaries, sediment sources, and the longitudinal organisation of macroinvertebrate fauna along river systems. Can. J. Fish. Aquat. Sci. 58(4) : 824-840.

Robinson C.T., Uehlinger U. \& Monaghan M.T., 2003. Effects of a multi-year experimental flood regime on macroinvertebrates downstream of a reservoir. Aquat. Sci. 65(3) : 210-222.

Rolls R.J., Sheldon F. \& Marsh N., 2012. Macroinvertebrate responses to prolonged low flow in sub-tropical Australia, National Water Commission, Canberra, $30 \mathrm{p}$.

Rosenberg D.M., Danks H.V. \& Lehmkuhl D.M., 1986. Importance of insects in environmental impact assessment. Environ. Manage. 10(6) : 773-783.

Rundle S.D., Jenkins A. \& Ormerod S.J., 1993, Macroinvertebrate communities in streams in the Himalaya, Nepal. Freshwater Biol. 30 : 169-180.

Sangpradub N. \& Boonsoong B., 2006. Identification of Freshwater Invertebrates of the Lower Mekong River and its Tributaires. Mekong River Commission, Vientiane, LAO PDR, $267 \mathrm{p}$.

Schlosser I.J., 1992. Effects of life-history attributes and stream discharge on filterfeeder colonization. J. N. Am. Benthol. Soc. 11(4) : 366-376.

Souksavath B. \& Nakayama M., 2013. Reconstruction of the livelihood of resettlers from the Nam Theun 2 hydropower project in Laos. Int. J. Water Resour. $D$ $29: 71-86$.

Sparks R.E., 1995. Need for ecosystem management of large rivers and their floodplains. Bioscience 45(3) : 168-182.

Sparks R.E., Nelson J.C. \& Yin Y., 1998. Naturalization of the flood regime in regulated rivers. Bioscience 48 : 706720.

Stanford J.A., Ward J.V., Liss W.J., Frissell C.A., Williams R.N., Lichatowich J.A. \& Coutant C.C., 1996. A general protocol for restoration of regulated rivers. US Department of Energy Publications, $43 \mathrm{p}$.

Stevens L.E., Shannon J.P. \& Blinn D.W., 1997. Colorado River benthic ecology in Grand Canyon, Arizona, USA: dam, tributary and geomorphological influences. Regul. River. 13(2) : 129-149.

Strong E.E., Gargominy O., Ponder W.F. \& Bouchet P., 2008. Global diversity of gastropods (Gastropoda; Mollusca) in freshwater. Hydrobiologia 595 : 149-166.

Suren A.M., 1994. Macroinvertebrate communities of streams in western Nepal: effects of altitude and land use. Freshwater Biol. 32(2) : 323-336.

ter Braak C.J.F. \& Smilauer P., 1998. CANOCO Reference Manual and User's Guide to Canoco for Windows: Software for Canonical Community Ordination (version 4), Microcomputer Power, Ithaca, New York, $352 \mathrm{p}$.

Thani I. \& Phalaraksh C., 2008. A preliminary study of aquatic insect diversity 
and water quality of Mekong River, Thailand. KKU. Sci. J. 36 (Suppl.) : 95-106.

Thorne R.S.J. \& Williams W.P., 1997. The response of benthic macroinvertebrates to pollution in developing countries: a multimetric system of bioassessment. Freshwater Biol. 37 : 671-686.

Tomanova S., Goitia E. \& Helešic J., 2006. Trophic levels and functional feeding groups of macroinvertebrates in neotropical streams. Hydrobiologia 556(1) : 251-264.

Vinson M.R., 2001. Long-term dynamics of an invertebrate assemblage downstream from a large dam. Ecol. Appl. 11: 711-730.

Vinson M.R. \& Hawkins C.P., 2003. Broadscale geographical patterns in local stream insect genera richness. Ecography 26 : 751-767.
Ward J.V. \& Stanford J.A., 1979. The ecology of regulated streams. New York: Plenum Press, $398 \mathrm{p}$.

Ward J.V. \& Stanford J.A., 1983. The serial discontinuity concept of lotic ecosystems. In: Fontaine T.D. III \& Bartell S.M. (Eds.), Dynamics of Lotic Ecosystems, Ann Arbor Science Publishers: Ann Arbor, 29-42.

Wilcox J.C., Holland W.D. \& Mc Dougald J.M., 1957. Relation of elevation of a mountain stream to reaction and salt content of water and soil. Can. J. Soil Sci. 37(1) : 11-20.

Ziv G., Baran E., Nam S., Rodríguez-Iturbe I. \& Levin S.A., 2012. Trading-off fish biodiversity, food security, and hydropower in the Mekong River Basin. P. Natl. Acad. Sci. USA 109(15) : 5609-5614. 


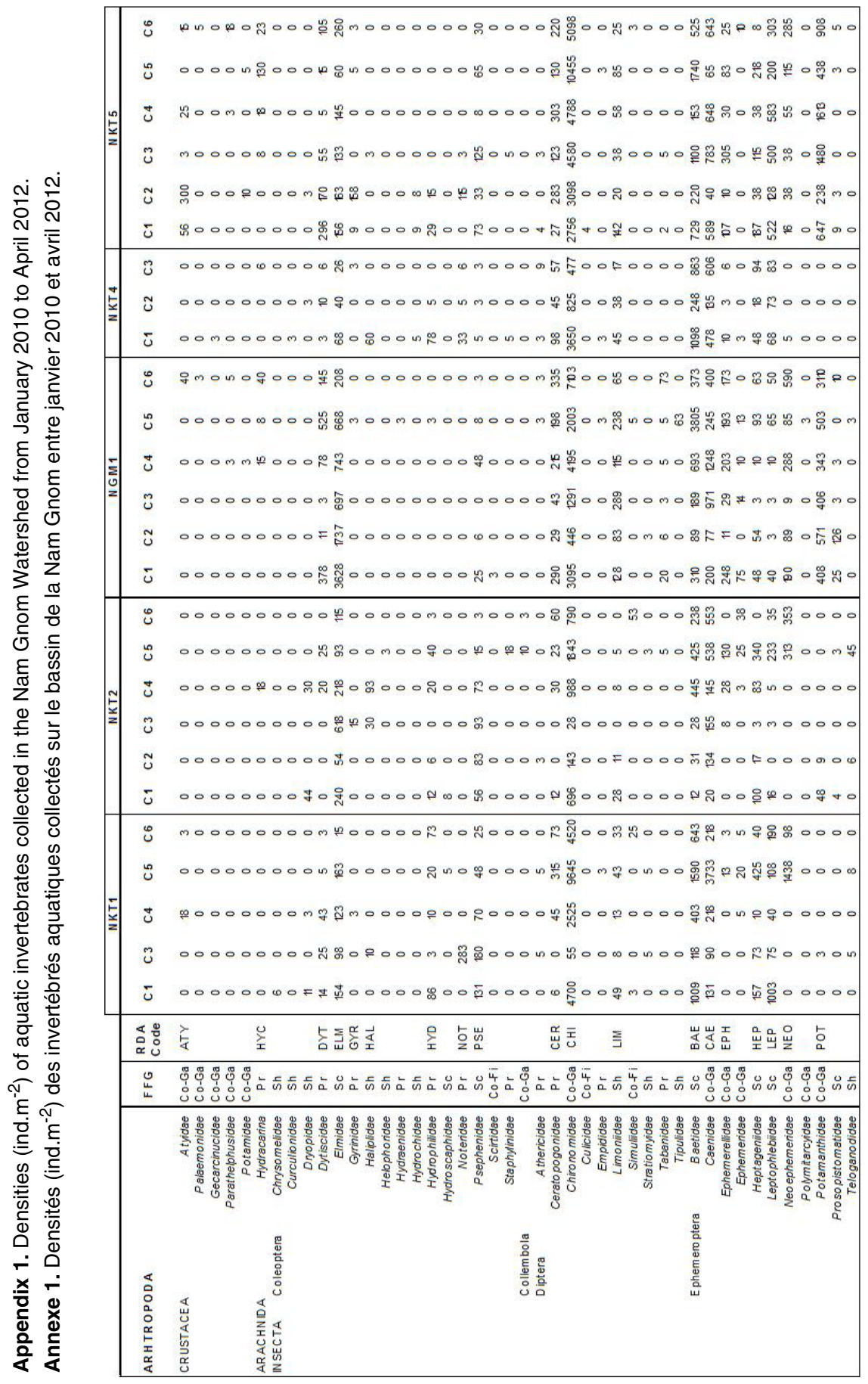




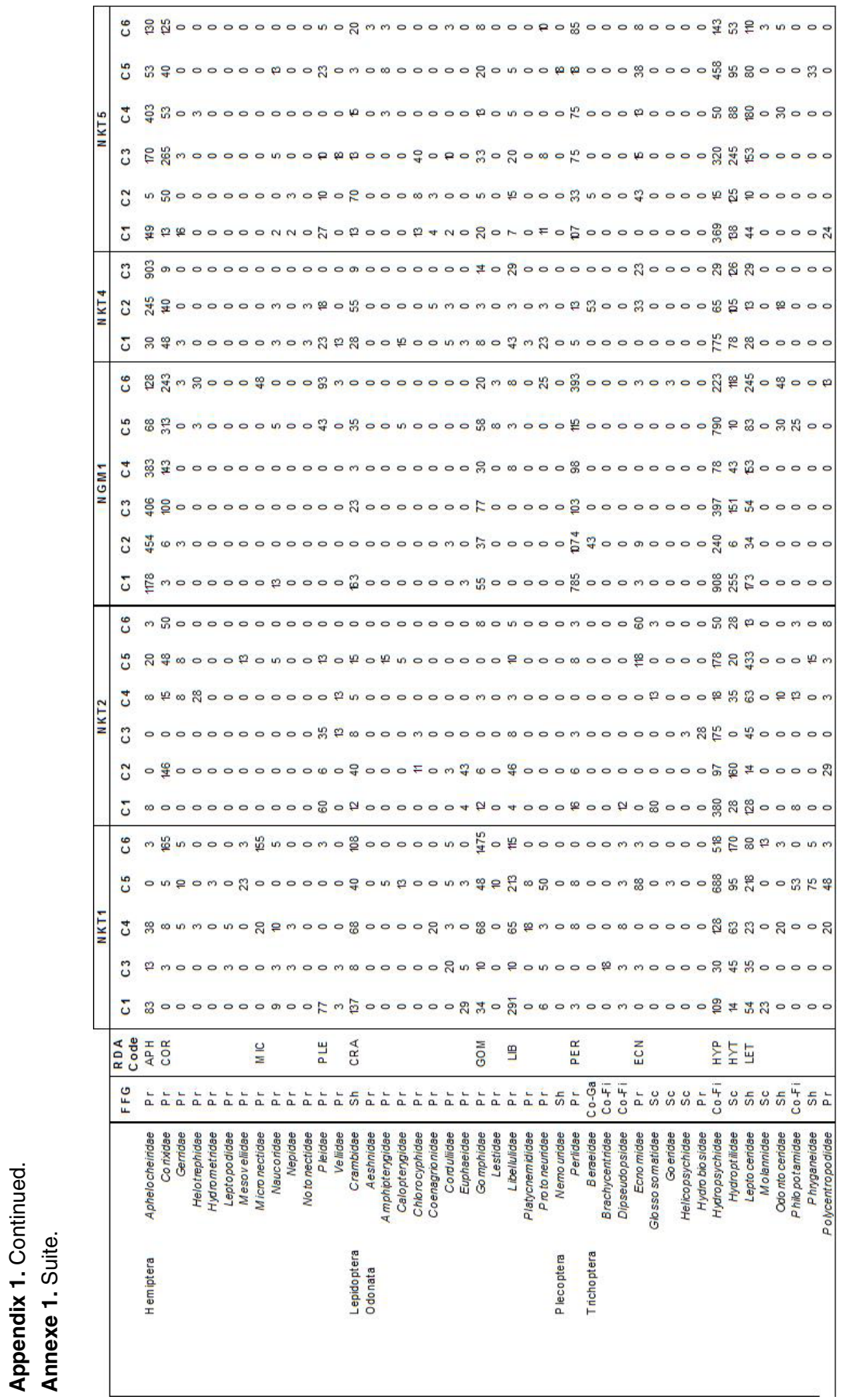




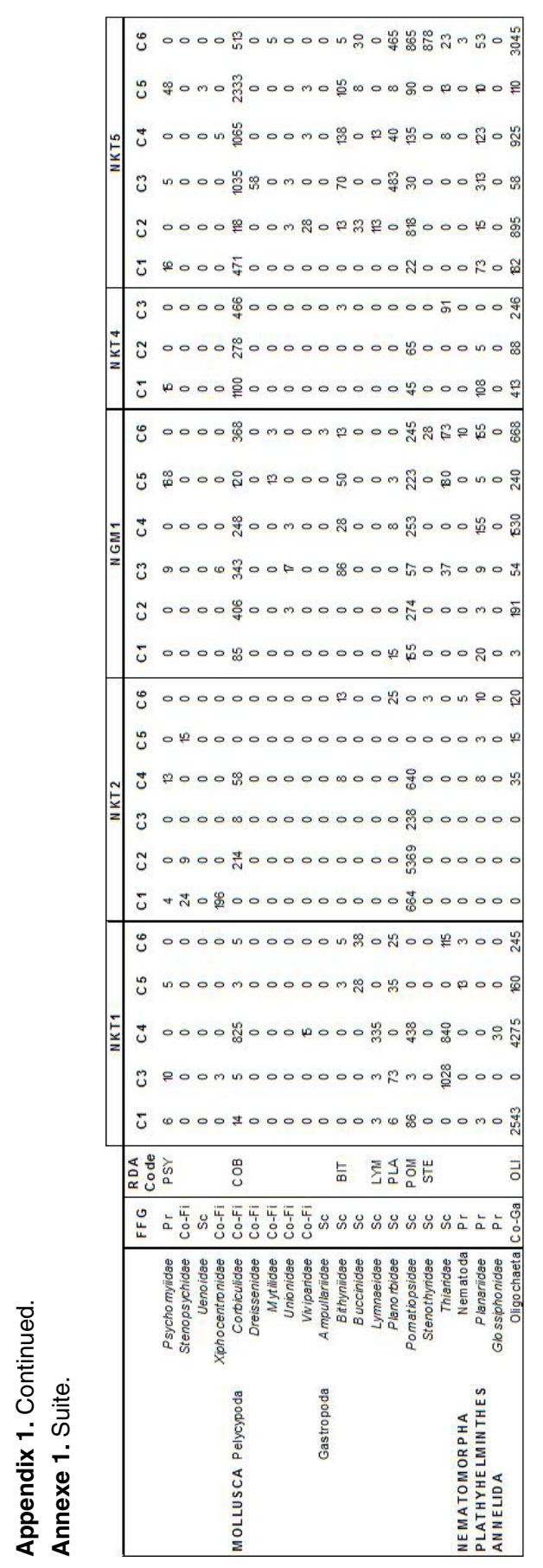


Appendix 2. Substrate types and current velocity mapping of the stations monitored in the Nam Gnom basin.

Annexe 2. Cartographie des types de substrat et des vitesses du courant des stations suivies sur le bassin de la Nam Gnom.

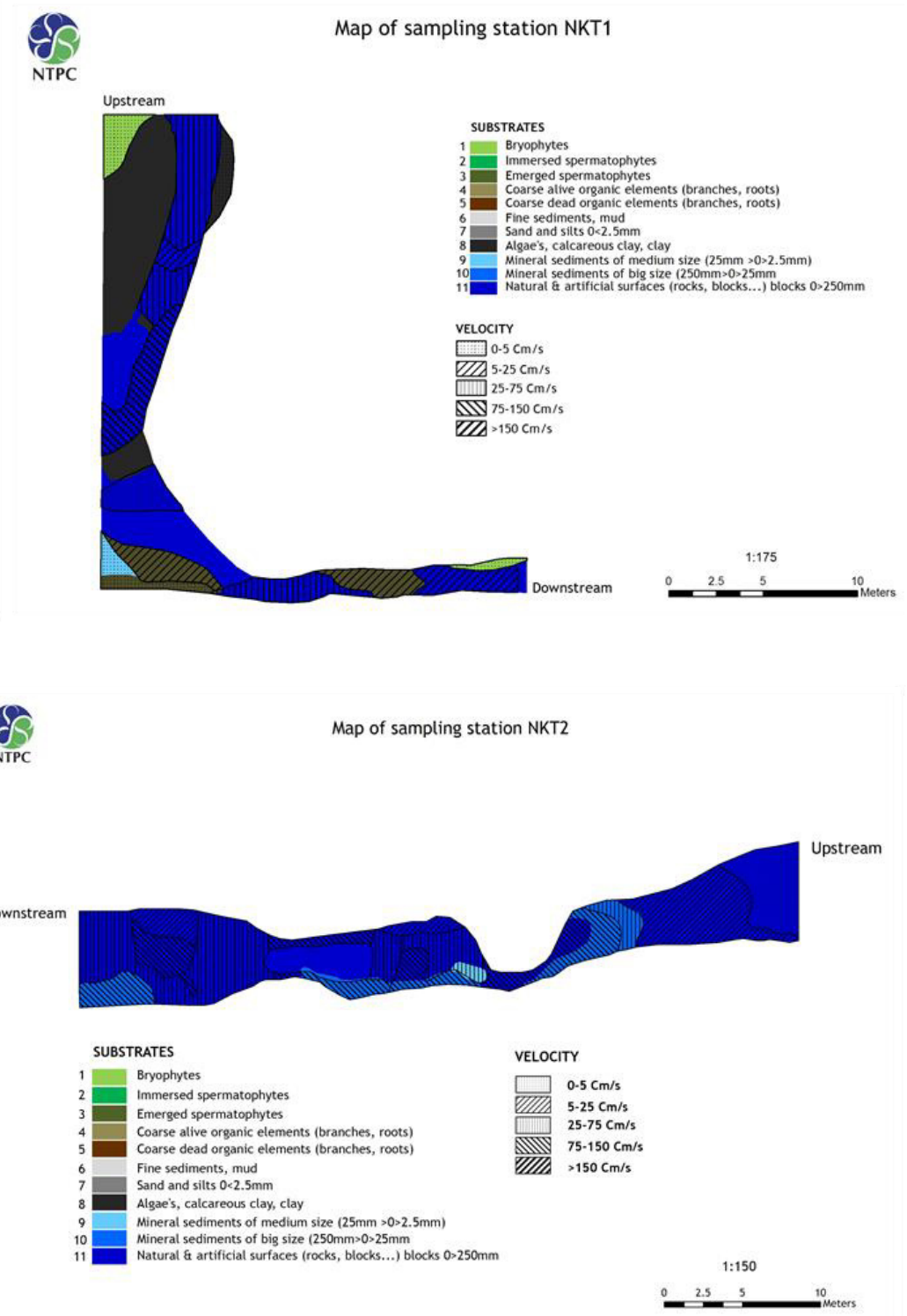


Appendix 2. Continued.

Annexe 2. Suite.
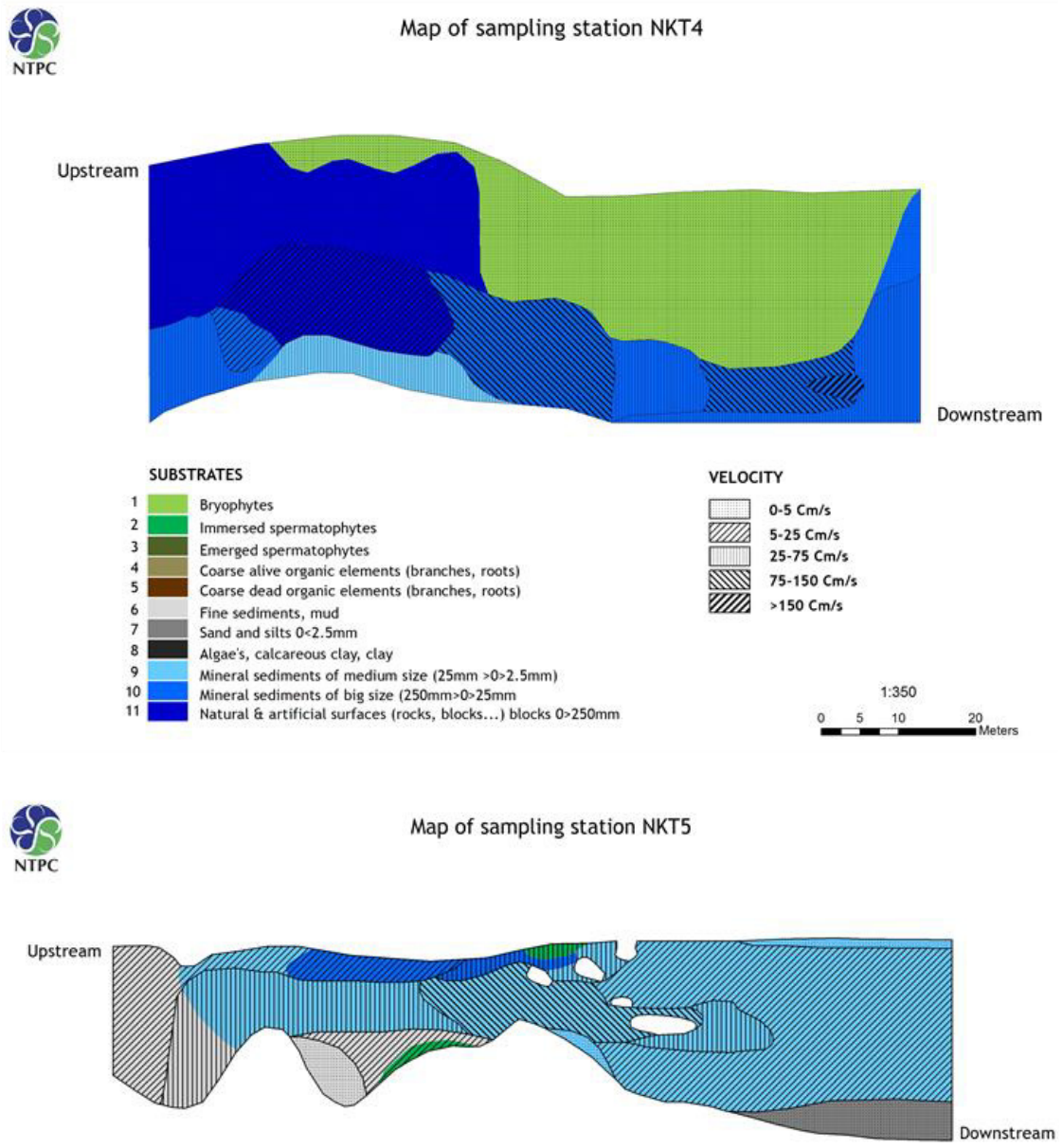

SUBSTRATES

VELOCITY
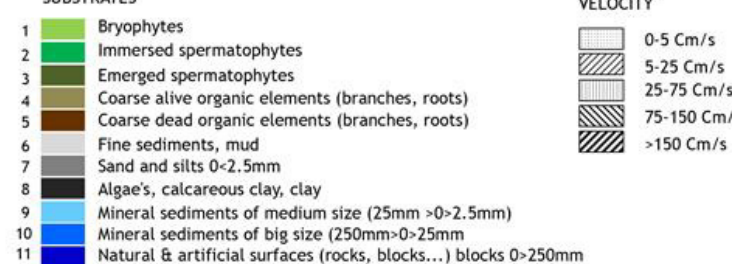

$>150 \mathrm{~cm} / \mathrm{s}$

Natural \&f artificial surfaces (rocks, blocks, .) blocks $0,250 \mathrm{~mm}$ 
Appendix 2. Continued.

Annexe 2. Suite.

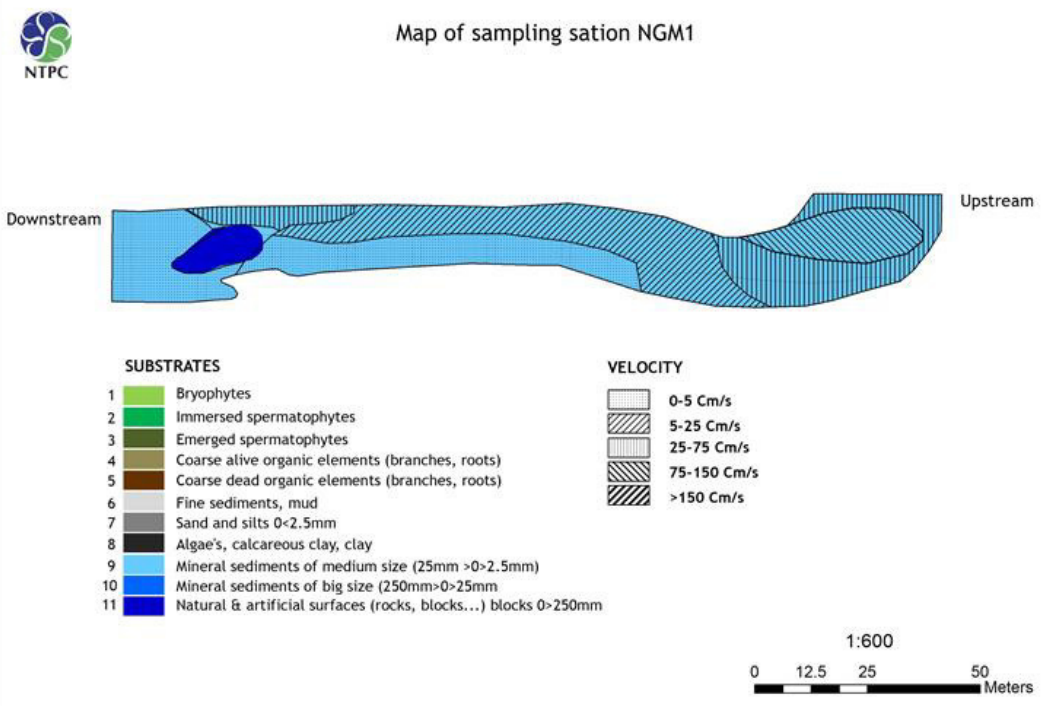

